\title{
Use of Honey in Stabilization of ZnO Nanoparticles Synthesized via Hydrothermal Route and Assessment of their Antibacterial Activity and Cytotoxicity
}

\author{
Shubha $\mathbf{P}^{1,2}$, Namratha $\mathbf{K}^{2}$, Jit Chatterjee ${ }^{3}$, Mustak $\mathrm{MS}^{3}$ and Byrappa $\mathbf{K}^{1^{*}}$ \\ ${ }^{1}$ Department of Materials Science, Mangalore University, India \\ ${ }^{2}$ Centre for Materials Science and Technology, University of Mysore, India \\ ${ }^{3}$ Department of Applied Zoology, Mangalore University, India
}

Submission: April 01, 2017; Published: May 12, 2017

*Corresponding author: Byrappa K, Department of Materials Science, Mangalore University, India, Email: kbyrappa@gmail.com

\begin{abstract}
Zinc oxide has found immense application in the field of medicine, dentistry and cosmetics. Its nano variety is extensively explored for potential medical applications. Several chemical reducing and stabilizing agents are used in synthesis $\mathrm{ZnO}$, which are hazardous to health and environment. In the current study, Zinc oxide nanoparticles were synthesized using aqueous solution of natural honey as reducing and stabilizing agent using zinc acetate as metal ion source utilizing hydrothermal technique. Synthesized nanoparticles were characterized using Powder X-ray diffraction, UV-Visible spectroscopy, Field-emission scanning electron microscopy and dynamic light scattering. Formation of ZnO nanoparticles was confirmed by diffraction pattern matching the JCPDS file 36-1451 and typical UV absorption spectra placed at $370 \mathrm{~nm}$ due to surface Plasmon resonance of $\mathrm{ZnO}$ nanoparticles. Average size of nanoparticles was $\sim 49 \mathrm{~nm}$ with monomodal distribution.

Antibacterial activity of different aliquots of synthesized $\mathrm{ZnO}$ was assayed against Streptococcus mutans, using colony counting method which showed that $\mathrm{ZnO}$ nanoparticles had inhibitory effect up to concentration of $25 \mu \mathrm{g} / \mu \mathrm{L}$. When the cytotoxicity of material was tested against Balb 3T3 fibroblast cell lines of mice using CCK 8 assay, it showed growth percentage of $83 \%$ at $10 \mu \mathrm{L}$ concentration which linearly decreased with concentration. From the current study, authors conclude that aqueous solution of honey has been successfully used in benign hydrothermal synthesis of $\mathrm{ZnO}$ nanoparticles which were antibacterial to S. mutans and biocompatible with selected cell lines. This material can be further evaluated using other advanced toxicological assays to develop the material for clinical applications.
\end{abstract}

Keywords: Hydrothermal; ZnO; Streptococcus mutans; Balb 3T3 fibroblasts; Cytotoxicity

\section{Introduction}

Zinc oxide is a material having enormous application in the field of medicine, dentistry and cosmetics. It is an inorganic white colored solid insoluble in water and currently listed as Generally Listed As Safe material (GRAS) by food and drug administration. The nanoparticles of $\mathrm{ZnO}$ has found enormous application in the field of medicine and cosmetics [1,2]. At the same time, there is also raising issues on toxicity of $\mathrm{ZnO}$ nanoparticles and their subsequent applications in the field of medicine $[3,4]$. The organic stabilizers used in the synthesis of metal oxide nanoparticles in general and $\mathrm{ZnO}$ nanoparticles in particular are known to possess toxicity, hence are non-biocompatible and most of them are insoluble in water. The common stabilizing agents like hexadecylamine, troctylphosphine oxide, alkylpyridine, organic thiols, oleic acids etc are known to cause toxicity [5]. Colloidal $\mathrm{ZnO}$ has been mostly produced in aqueous or alcoholic solutions by direct reaction of zinc compounds with bases in the presence of appropriate stabilizers [6].

There are several methods to synthesize $\mathrm{ZnO}$ nanoparticles which include chemical vapor synthesis, Laser ablation, solvothermal, thermal decomposition and sol-gel method $[7,8]$, which require use of costly and hazardous chemicals, use of enormous energy and associated environmental hazards. Hence the recent development in the field of nanotechnology research is more towards the green chemistry approaches, wherein the natural sources are used as stabilizing, reducing and capping agents in controlling the size and morphology of nanoparticles, specially the once whose biological applications are intended. In this respect, plant extracts of different parts of the plants in several organic solvents, microorganisms, carbohydrates and proteins have been used in the synthesis of nanoparticles [9-11]. 
Study on use of glucose and fructose as a stabilizing and reducing agents in synthesis of nanoparticles is gaining much popularity these days. There are reports that monosaccharides like glucose having linear chain and containing aldehyde groups are excellent reducing agents and it was also found earlier that fructose is capable of participating in the synthesis of metal nanoparticles of various morphologies [12]. As honey is a rich source of both these mentioned monosaccharides, in the current study, we used it as reducing and stabilizing agent. Furthermore, typical synthesis method used in synthesizing Zno nanoparticles is The hydrothermal technique.

It helps in processing monodispersed and highly homogeneous nanoparticles with precise control over the size and shape of nanoparticles. It also offers advantage of reduced energy consumption, better nucleation control, avoidance of environmental pollution etc [13]. $\mathrm{ZnO}$ is a common metal oxide used in restorative dentistry in the form of its chelate the Zinc eugenolate as a temporary and intermediate restorative material. The $\mathrm{ZnO}$ nanomaterial is known to possess antibacterial activity against many dental pathogens, especially the Streptococcus mutans which is the primary organism causing dental caries [14], hence in the current study, the antibacterial activity of the title material was assayed against $S$. mutans using spread plate technique [15].

As mentioned earlier, there is a raising question on toxicity profile of nanomaterials meant for food and medicinal applications, hence in the current study, we also evaluated the cytotoxicity of synthesized ZnO using Balb 3T3 mouse fibroblast cell lines [16], as the fibroblasts are the main component cells of periapical and periodontal tissues coming in contact with dental restorative materials.

\section{Materials and methods}

Zinc acetate (99.9\%) used in the current study was obtained from Alfa aeser, Sodium hydroxide from Loba-chemie and ultrapure water of resistivity $18.5 \mathrm{M} \Omega$ (Pure labs Q, ELGA). Pure honey was obtained from the nearby local market (Dabur India Pvt ltd). The Balb 3T3 cell lines used in the present study were obtained from National Centre for Cell Sciences (NCCS) Pune. Pure culture of S. mutans (MTCC 890) was obtained from Microbial Type Cell Culture and Gene Banking, Chandigarh. The Brain heart infusion broth and agar were procured from HIMEDIA Pvt Ltd.

\section{Hydrothermal synthesis of ZnO nanoparticles}

$1 \mathrm{M}$ solution of Zinc acetate was dissolved in ultrapure water of resistivity $18.5 \mathrm{M} \Omega$, which was stirred continuously at $60^{\circ} \mathrm{C}$. To this $0.1 \mathrm{M}$ sodium hydroxide was slowly added drop wise until the $\mathrm{pH}$ reached 9 , at which a yellow colored precipitate was obtained. This was collected and washed several times with ultrapure water. Later the mixture was transferred to Teflon liner contained in stainless steel general purpose hydrothermal autoclave (SS 316). To this reaction mixture, $0.5 \mathrm{ml}$ of honey was added as stabilizing and capping agent and treated under autogenous pressure at $180{ }^{\circ} \mathrm{C}$ for $12 \mathrm{hr}$. Further, the autoclaves were allowed to cool and the obtained product was collected and washed several times with ultrapure water and finally with ethyl alcohol to remove the organic impurities and vacuum dried [17]. The obtained $\mathrm{ZnO}$ nanoparticles were sintered at $700{ }^{\circ} \mathrm{C}$ to improve crystallinity of the material.

\section{Analytical methods}

Hydrothermally synthesized $\mathrm{ZnO}$ nanoparticles were characterized using powder XRD, UV-Vis Spectroscopy, Fieldemission Scanning Electron microscopy and Dynamic light scattering technique. Structure of $\mathrm{ZnO}$ nanostructures were analyzed using PXRD studies using Rigaku smart Lab-II, CuK $\alpha$ radiation. The optical absorption spectra were recorded using UV-Vis spectrophotometer (ELICO SA 165, India) in wavelength range of 200 to $800 \mathrm{~nm}$. External morphology of synthesized nanoparticles was determined using FESEM (Carl-Zeiss) and particle size was obtained by DLS using Microtrac Zeta analyzer.

\section{Assessment of antibacterial activity using spread plate technique}

$1 \mathrm{~g}$ of $\mathrm{ZnO}$ nanoparticles were dispensed in $1 \mathrm{ml}$ ultrapure water $(1 \mu \mathrm{g} / \mu \mathrm{l})$ in a clean and dry Eppendorf's tube and sonicated for $45 \mathrm{~min}-1 \mathrm{hr}$ to obtain a complete dispersion of $\mathrm{ZnO}$. This was further serial diluted up to $0.125 \mu \mathrm{g} / \mu \mathrm{L}$. $25 \mu \mathrm{L}$ of fresh culture of $S$. mutans (in BHI broth) whose concentration was adjusted to $10^{6}$ $\mathrm{CFU} / \mathrm{mL}$ was added into each of the different concentration of $\mathrm{ZnO}$ dispersion. The tubes were sealed carefully and maintained at $37^{\circ} \mathrm{C}$ with continuous shaking overnight.

Pen-Strep was used as negative control and overnight pure culture was maintained as positive control. After $24 \mathrm{hr}$ the Eppendorf tubes were removed from shaker. $20 \mu \mathrm{L}$ of each of the test sample was spread on the surface of BHI agar and incubated at $37{ }^{\circ} \mathrm{C}$ overnight. Next day the petri-plates were observed for growth or inhibition and a colony counting was performed using manual colony counter (Vision Microsystems).

\section{Cytotoxicity studies of ZnO nanoparticles}

Mouse fibroblast cell lines (Balb 3T3) used in the current study was obtained from NCCS, Pune and were cultured in DMEM supplemented with $10 \%$ fetal bovine serum (FBS) and antibiotics (Himedia, $50 \mu \mathrm{g} / \mathrm{ml}$ penicillin and $50 \mu \mathrm{g} / \mathrm{ml}$ streptomycin) in 96 well-culture plates. Cultured cells were incubated at $37{ }^{\circ} \mathrm{C}$ in humidified atmosphere containing $5 \% \mathrm{CO}_{2}$. Cells were regularly fed with Dulbecco's modified Eagles Medium (DMEM) and their growth was monitored by microscopic observations. Cells were regularly passaged by trypsinization with $0.1 \%$ trypsin in phosphate buffer saline (PBS).

CCK 8 allows sensitive colorimetric assays to determine cell viability in cell proliferation and cytotoxicity. The test 
was performed to evaluate cytotoxic effect of hydrothermally synthesized $\mathrm{ZnO}$ nanoparticles. The cells were seeded separately on 96-well microplates (Himedia) at density of 12,000 cells/ well and were allowed to grow for $24 \mathrm{~h}$ in DMEM containing $10 \%$ FBS. The cells were incubated at $37{ }^{\circ} \mathrm{C}$ in a $99 \%$ humidified atmosphere containing $5 \% \mathrm{CO}_{2}$.

$1 \mathrm{~g}$ of $\mathrm{ZnO}$ was dispensed into a $2 \mathrm{ml}$ capacity Eppendorf's tube to which $1 \mathrm{ml}$ of water ultra -pure was added and further the material was ultrasonicated for $45 \mathrm{~min}-1 \mathrm{hr}$ to obtain a complete dispersion. This dispersion was used for evaluation of cell viability of different selected cell lines. To check the cell viability, the cell lines were treated with $\mathrm{ZnO}$ (from $10 \mu \mathrm{l}$ to $1 \mu \mathrm{l}$ ) and incubated for $24 \mathrm{~h}$. After $24 \mathrm{~h}$ incubation, $10 \mu \mathrm{l}$ of CCK-8 (Sigma Aldrich) solution was added to each of the 96 well -plate and incubated at $37{ }^{\circ} \mathrm{C}$ in $99 \%$ humidified atmosphere containing $5 \% \mathrm{CO}_{2}$ for $4 \mathrm{hr}$. Post incubation, absorbance was measured at $450 \mathrm{~nm}$ using a microplate reader. Percentage cell growth was calculated from absorbance reading using equation

$$
\text { Percentage growth }=\frac{\text { Absorbance of Sample }- \text { Absorbance of Blank }}{\text { Absorbance of confluent Cells-Absorbance of Blank }} \times 100
$$

\section{Results and Discussion}

\section{Analytical methods}

Powder XRD: Purity of the phase of ZnO nanoparticles was measured by powder XRD analysis using Rigaku Mini Flux II (Japan) instrument using $\mathrm{Cu}$ as target material (1.5406 ̊). Crystal lattice indices of $\mathrm{ZnO}$ was confirmed by diffraction peaks observed at different $2 \theta$ values. The average crystallite size was further determined using Scherrer formula

$$
D=\frac{0.9 \lambda}{\beta \cos \theta}
$$

Where,

\section{$\mathrm{D}=$ Average crystallite size}

$\Theta=$ Bragg angle in degrees

$\beta=$ Angular line width at half maximum intensity

$\lambda=$ Wavelength of $X$ ray used

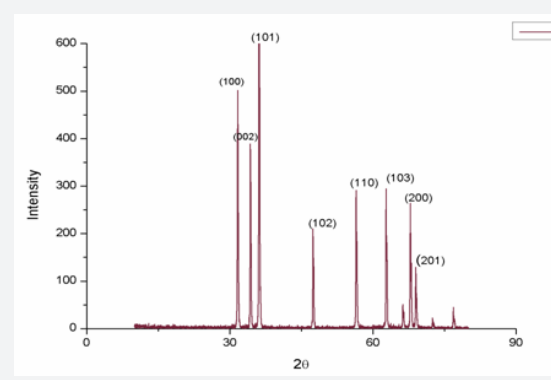

Figure 1: PXRD pattern of $\mathrm{ZnO}$ with different diffraction peaks.

Figure 1 shows the PXRD pattern of hydrothermally synthesized $\mathrm{ZnO}$ nanoparticles. Diffraction peaks were observed at $2 \theta$ values of $31.7^{\circ}, 34.3^{\circ}, 36.1^{\circ}, 47.4^{\circ}, 56.5^{\circ}, 62.9^{\circ}, 66.2^{\circ}$, $67.8^{\circ}$ and $68.9^{\circ}$ corresponding to lattice planes (100), (002), (101), (100), (110), (103), (200), (112) and (201) respectively. The peaks have been attributed to hexagonal phase of $\mathrm{ZnO}$ (JCPDS file: 36-1451) [18]. All diffraction peaks are indexed according to the hexagonal phase of $\mathrm{ZnO}$. The average crystallite size determined using Scherrer formula is $39 \mathrm{~nm}$.

UV-Visible Spectroscopy: UV-Vis spectroscopy of synthesized $\mathrm{ZnO}$ nanoparticles was performed in wavelength range between 200-800 nm (Elico SA 165, India) and absorption value was replotted using origin 8 software. Presence of maximum absorption at around $372 \mathrm{~nm}$ confirms the presence of $\mathrm{ZnO}$ nanoparticles which is due to surface plasmon resonance of $\mathrm{ZnO}$ nanoparticles. A sharp peak was seen at $372 \mathrm{~nm}$ correlating the formation of $\mathrm{ZnO}$ as supported by previous literature [19]. Figure 2 shows the UV-visible spectroscopy data of synthesized ZnO nanoparticles.

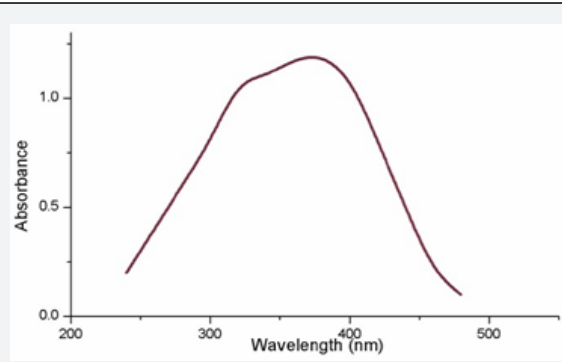

Figure 2: UV-Vis spectroscopy graph of $\mathrm{ZnO}$ nanoparticles with maximum absorption at $372 \mathrm{~nm}$.

Particle size analysis using dynamic light scattering: Average size of the synthesized $\mathrm{ZnO}$ nanoparticles was measured using dynamic light scattering technique. In this method, Particle size can be determined by measuring the random changes in the intensity of light scattered from a suspension or solution. In the current study, results of the analysis show an average particle size distribution of $49 \mathrm{~nm}$ with 95 percentiles of particles being at $48.9 \mathrm{~nm}$ size range as seen in Figure 3.

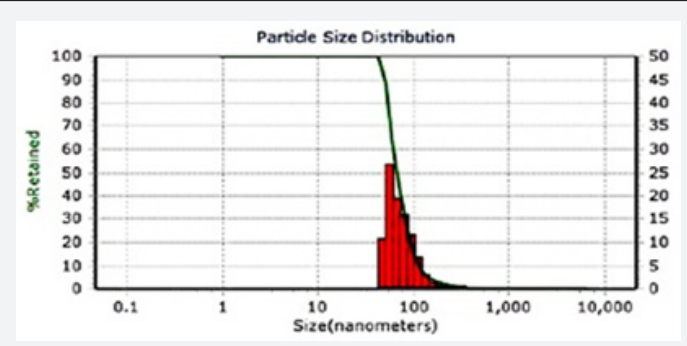

Figure 3: Average particle size distribution of $\mathrm{ZnO}$ nanoparticles.

FESEM results: FE-SEM provides higher resolution in the whole range of accelerating voltages hence gives better picture quality and resolution compared to SEM. In the current study, FESEM of synthesized ZnO nanoparticles were performed using ULTRA 55, FESEM (Karl Zeiss). The particle dimensions and morphology of the as prepared $\mathrm{ZnO}$ nanoparticles were examined at different resolutions. Figure 4 shows the images 


\section{Global Journal of Nanomedicine}

of $\mathrm{ZnO}$ nanoparticles which look spherical in morphology with agglomeration, a common feature of $\mathrm{ZnO}$ nanoparticles [20].
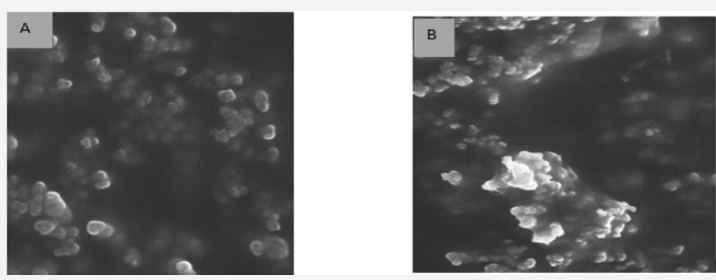

Figure 4: $\mathrm{A} \mathrm{ZnO}$ nanoparticles at $200 \mathrm{~nm}$ resolution showing almost spherical particles agglomerated;

B: FESEM image at $1 \mu \mathrm{m}$ resolution showing agglomeration.

Antibacterial activity of ZnO nanoparticles against $\boldsymbol{S}$ mutans: After $24 \mathrm{hr}$ incubation at $37^{\circ} \mathrm{C}$, the Petri plates were observed for growth or inhibition. The synthesized material showed inhibition of growth up to $0.25 \mu \mathrm{g} / \mu \mathrm{L}$, which is also its minimum inhibitory concentration. At lesser concentration, there was growth of round streptococcal colonies on the surface of BHI agar [21]. Positive control showed confluent growth of microbe and negative control showed complete inhibition. By this we can infer that as synthesized nanoparticles of $\mathrm{ZnO}$ possess antibacterial activity at concentrations as low as $0.25 \mu \mathrm{g} /$ $\mu \mathrm{L}$. Figure 5 shows the growth and inhibition of $S$ mutans under the influence of $\mathrm{ZnO}$ nanoparticles.
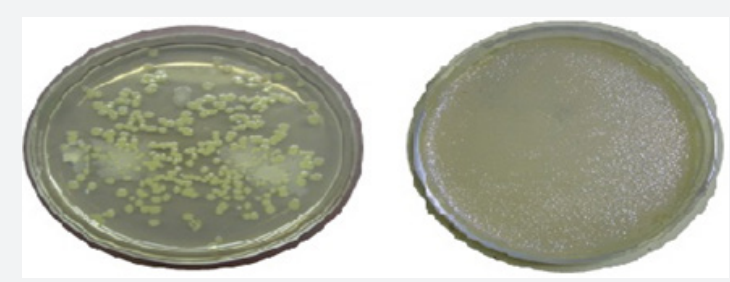

Figure 5: Petri plates with confluent growth of $S$ mutans on $\mathrm{BHI}$ agar surface and also the typical image of inhibition caused by $0.25 \mu \mathrm{g} / \mathrm{mL}$ of $\mathrm{ZnO}$ nanoparticles.

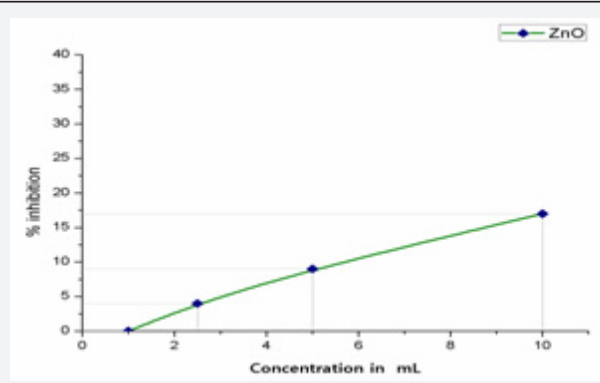

Figure 6: Percentage inhibition graph of Balb 3T3 fibroblast cell lines by $\mathrm{ZnO}$ nanoparticles.

Cytotoxicity of ZnO on balb 3T3 cell lines: CCK 8 assay is water soluble tetrazolium salt based assay to screen the possible adherent cellular toxicity of various material. This assay measures cellular viability of fibroblast cells upon exposure to different concentrations of test substances. The graph remained almost linear as represented in Figure 6. At the highest tested concentration of $10 \mu \mathrm{L}$ the $\mathrm{ZnO}$ showed good growth promotion of $83 \%$ with only $17 \%$ inhibition in proliferation of cells. At the lower concentrations, the proliferative activity increased and touched base line at $1 \mu \mathrm{L}$ concentration. This shows that the synthesized material is not toxic to the selected cell lines at the tested concentrations. It has been proven earlier that large sized ZnO nanoparticles produces comparatively lower cytotoxicity, even though a base line for nanoparticle size determining the toxicity is not yet established, but in typical experiment performed by current authors the nanoparticles were nearly $49 \mathrm{~nm}$ which proved to be less toxic [22].

\section{Conclusion}

From the current study, we conclude that honey was successfully used as stabilizing and reducing agent in hydrothermal synthesis of $\mathrm{ZnO}$ nanoparticles. Thus synthesized material had good antibacterial activity against $S$. mutans, the primary organism causing dental caries. Also, the material remained negligibly toxic to Balb $3 \mathrm{~T} 3$ mouse cell lines which declined with reduction in concentration. Hence, the title material can be considered for further animal trials to subsequently develop a product with potential antimicrobial application in dentistry with no toxic effects.

\section{Acknowledgement}

This work has been supported by University Grants Commission, India, under University with Potential for excellence programme (UPE), University of Mysore. We thank Mr C. S. Vicas, Researcher, Centre for Materials Science and Technology, Vijnan Bhavan, Mysuru for extending his valuable support in conducting cell line studies.

\section{References}

1. Sabir S, Arshad M, Chaudhari SK (2014) Zinc Oxide Nanoparticles for Revolutionizing Agriculture: Synthesis and Applications. Scientific WorldJournal pp.925494.

2. Kuo LC, Wang LC, Ko HH, Wang SW, Chang MK, et al. (2010) Synthesis of $\mathrm{ZnO}$ nanocrystalline powders for cosmetic applications. Ceramic International 36(2): 693-698.

3. Kim YR, Park JI, Lee EJ, Park SH, Seong NW, et al. (2014) Toxicity of $100 \mathrm{~nm}$ zinc oxide nanoparticles: a report of 90-day repeated oral administration in Sprague Dawley rats. Int J Nanomedicine 9(2):109126.

4. Heng BC, Zhao X, Xiong S, Ng KW, Boey FY, et al. (2010) Toxicity of zinc oxide ( $\mathrm{ZnO})$ nanoparticles on human bronchial epithelial cells (BEAS2B) is accentuated by oxidative stress. Food Chem Toxicol 48(6): 17621766.

5. Faleni N, Moloto MJ (2013) Effect of glucose as stabilizer of $\mathrm{ZnO}$ and CdO Nanoparticles on the morphology and optical Properties. IJRRAS 14(1): 127-135.

6. Koch U, Fojtik A, Weller H, Henglein A (1985) Photochemistry of semiconductor colloids. Preparation of extremely small $\mathrm{ZnO}$ particles, fluorescence phenomena and size quantization effects. Chemistry and physics letters 122(5): 507-510.

7. Lobiak EV, Shlyakhova EB, Bulusheva LG, Pluyusnin PV, Shubhin PE, et al. (2009) Characterization of ZnO Nanoparticles Grown by Laser 
Ablation of a Zn Target in Neat Water. Bulletin of Korean Chemical society 30: 1616-1618.

8. Wang C, Shen E, Wang E, Gao L, Kang Z, et al. (2006) Controllable synthesis of $\mathrm{ZnO}$ nanoparticles via surfactant assisted alcohol thermal process at low temperature. Current Application in Physics 6: 499-502.

9. Sangeetha G, Rajeshwari S, Venkatesh R (2011) Green synthesis of Zinc oxide nanoparticles by Aloe barbadensis miller leaf extract: Structure and optical properties. Material Research Bulletin 46(12): 2560-2566.

10. Anandaraj LAF, Jayalakshmi E (2015) Biosynthesis of Zinc Oxide Nanoparticles from Azadirachta indica for Antibacterial Photocatalytic Applications. Oriental Journal of Chemistry 31: 55-56.

11. Alejandri J, Gonzalaez F, Juan A, Neizo MS (2016) Synthesis and Characterization of Silver Nanoparticles Prepared with Honey: The Role of Carbohydrates. Anal Letters pp 877-888.

12. Panigrahi S, Kundu S, Ghosh S, Nath S, Pal T (2004) General method of synthesis of metal nanoparticles. Journal of nanoparticle Research 6(4): 411-414.

13. Byrappa K, Adischari T (2007) Hydrothermal technology for nanotechnology, Progress in crystal growth and characterization of materials (53) 117-166.

14. Mirhashemi A, Bahador A, Kassaee MZ, Daryakenari G, Sadegh M, et al. (2013) Antimicrobial Effect of Nano-Zinc Oxide and Nano-Chitosan Particles in Dental Composite Used in Orthodontics. Journal of Medical Bacteriology 2(2-3): 1-10.
15. Zobell C E (1954) Bacteriology of sea Fundamentals of Bacteriology. McGraw Hill book Co New York pp. 503-516.

16. Aaronson SA, Todaro G J (1968) Development of 3T3-like lines from Balb/c mouse embryo cultures: Transformation susceptibility to SV40. J Cell Physiol 72(2): 141-148.

17. Vicas CS, Namratha K, Byrappa K, Yathirajan HS (2015) Preclinical Assessment of Zinc Ferrite Nanoparticles Synthesized Using D-Glucose by Hydrothermal Method. Journal of Chemical Biological and Physical Sciences Sec A 6: 105-116.

18. Talam S, Karumani S, Gunnam N (2012) Synthesis, characterization and spectroscopic properties of ZnO nanoparticles. ISRN Nanotechnology 10: 372500-372505.

19. Lin C, Li Y (2009) Synthesis of ZnO nanowires by thermal decomposition of zinc acetate dehydrate. Materials in Chemistry and Physics 113(1): 334-337.

20. Zhang L, Jiang Y, Ding Y, Povey M, York D (2007) Investigation into the antibacterial behaviour of suspensions of $\mathrm{ZnO}$ nanoparticles ( $\mathrm{ZnO}$ nanofluids). Journal of nanoparticle Research 9(3): 479-489.

21. Raghupathi KR, Koodli RT, Manna A C (2011) Size dependent bacterial growth inhibition and mechanism of antibacterial activity of Zinc oxide nanoparticles. Langmuir 27 (7): 4020-4028.

22. Baek M, Kim MK, Cho HJ, Lee JA, Yu J, et al. (2010) Nanosafe 2010: International Conference on Safe Production and Use of Nanomaterials. France.

Your next submission with JuniperPublishers
will reach you the below assets
- Quality Editorial service
- Swift Peer Review
- Reprints availability
- E-prints Service
- Manuscript Podcast for convenient understanding
- Global attainment for your research
- Manuscript accessibility in different formats
( Pdf, E-pub, Full Text, Audio)
- Unceasing customer service
Track the below URL for one-step submission
https://juniperpublishers.com/submit-manuscript.php

